\section{Géneros}

Multidisciplinary burnal of Gende Studies

\section{Hipatia Press}

www, hipatiapress.com

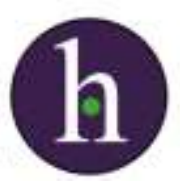

Instructions for authors, subscriptions and further details:

$\underline{\text { http://generos.hipatiapress.com }}$

\title{
Women, Business and Leadership Gender and Organizations
}

Maria del Socorro Ocampo Castillo ${ }^{1}$

1) Universidad de Barcelona. Spain

Date of publication: June 25th, 2019

Edition period: June-October 2019

To cite this article: Ocampo, M. (2019). Women, Business and Leadership Gender and Organizations. [Review of the Book]. Multidisciplinary Journal of Gender Studies, 8(2), 204-205 doi: 10.17583/generos.2019.4402

To link this article: $\underline{\text { http://dx.doi.org/10.17583/generos.2018.3833 }}$

PLEASE SCROLL DOWN FOR ARTICLE

The terms and conditions of use are related to the Open Journal System and to Creative Commons Attribution License (CC-BY). 
Ocampo Castillo -Women, Business and Leadership. [Book 204 Review]

\section{Review}

Antoniou, A., Cooper, C. \& Gatrell, C. Editors (2019). Women, Business and Leadership Gender and Organizations. Cheltenham: Edward Elgar Publishing.

his book is a compilation of the work of 46 researchers from 7 different universities and research centers who, from a multidisciplinary approach, expose the current situation of women in business and leadership positions in organizations.

In a general way, this publication intends to recognize the improvements that have been presented both in the legal and socio-cultural fields regarding the equality of women in the world of business and organizations. In the same way, it highlights the barriers and challenges faced by many women during the last decades to reach such improvements and those that still represent serious difficulties for the development of women in business and leadership positions.

The book is divided into three sections composed of a total of 26 chapters in total. The first section: Leadership and authority: women at the helm introduces and analyzes female leadership and entrepreneurial concepts. Aspects such as the value of women's leadership in times of economic crisis, the emotional implications of leadership and the discussion of legal perspectives from the individual and the institutional are examined. Throughout the nine chapters that make up this section, the authors present situations that exemplify how women in leadership roles in any area face specific challenges of their gender.

The second part Experience: How women in business and management negotiate their position, presents some of the aspects that affect the trajectory of women towards leadership positions. The first chapters of the section highlight the value of networks in the achievement of leadership positions and professional improvement. They also reveal how women do not have the same access as men to generate these networks. Chapters 12,13 and 14 discuss various phenomena that seek to describe and explain the low representation of women in leadership positions within businesses and organizations. Within this phenomenon, the term "glass ceiling" is analyzed and the concepts of 


\section{GÉNEROS-Multidisciplinary Journal of Gender Studies \\ Vol. 8 No.2 June 2019 pp. 204-205}

"labyrinth" and "concrete wall" are incorporated into it. Along the same lines, we reflect on gender stereotypes and norms and the different negative experiences experienced by women on the way to leadership positions. Chapter 16 gives special attention to pregnancy and the difficulties, stigmas and discrimination that this situation implies for women.

The final section Constraints: the structural and cultural impediments affecting women's career advancement, takes up some of the phenomena presented in the previous chapters regarding the limitations and challenges of women on their way to the top and the way this is treated in relation to practice and politics. Specific leadership experiences are studied in various sectors such as religious (presenting the case of the Church of England), the financial sector, sports and everyday life. This experiences also show different cultural contexts that allow to add to the reflections the implications that the uses and customs of each region entail in the development of the organizational and economic leadership of women.

The last chapter emphasizes the need to add to the debate on gender disparities in organizational studies the other differences that affect leadership and professional improvement. A more complete vision in the study of management and leadership has to take into account the impact on career advancement that differences of age, ethnicity, race, religion, nationality, sexual orientation and health have within the organizations.

It should be noted that, although the book is shown as a compendium of scientific publications and studies, it also examines particular experiences that illustrate the barriers that women have managed to overcome in order to reach the maximum levels within the organizations. These examples allow a practical contextualization of the restrictions that continue to represent a virtual inequality for the female gender. In this sense, the narrative, theoretical-practical style of the book allows it to be a reading of interest beyond the academic field.

Maria del Socorro Ocampo Castillo, Universidad de Barcelona mariaocampo1390@gmail.com

2019 Hipatia Press

ISSN: 2014-3613

doi: $10.17583 /$ generos.2019.4402 